\title{
Dissolved Oxygen Profiles and Its Problems at Lake Maninjau, West Sumatra - Indonesia
}

\author{
Luki Subehi $^{\text {a,*, Iwan Ridwansyah }}{ }^{\text {a, b }}$, Takehiko Fukushima ${ }^{\text {b }}$ \\ ${ }^{a}$ Research Center for Limnology LIPI; Kompleks LIPI Cibinong, Jalan Raya Bogor, Km. 46, Cibinong 16911; \\ *luki@limnologi.lipi.go.id \\ ${ }^{\mathrm{b}}$ Ibaraki Kasumigaura Environmental Science Centre -Japan
}

Received 30 November 2020

Accepted 13 December 2020

Published 17 December 2020

\begin{abstract}
In general, the tropical lake in Indonesia is one of the unique ecosystems which are functioning in both ecological and economic services. This study aims to analyze the dissolved oxygen profile of caldera tropical lake represented by Lake Maninjau at West Sumatera, Indonesia, and its impacts. Lake Maninjau is not only for culture fisheries but also serves as important hydroelectricity power. Surveys at Lake Maninjau were conducted in August 2006, March 2014, September 2017, and April 2018. The results showed that the average depth is $105 \mathrm{~m}$. It covers 13,260 ha of an area with an elevation of $461.5 \mathrm{~m}$ above sea level and a maximum depth of $165 \mathrm{~m}$. The lake water comes from rainfall, small rivers, and the surrounding groundwater, with one outflow in the Batang Antokan River. Based on the measurement, it was observed that decreasing dissolved oxygen levels occurred at the surface to the depth of $40 \mathrm{~m}$ in 2006, and changed from surface to a depth of $12 \mathrm{~m}$ in 2018 indicating the worse condition of water quality compared with the previous years. Recently, bad water quality with mass mortality of cultured fish often occurs. Next, the percentage of fish cages area at Lake Maninjau in 2017 was $0.43 \%$. Besides human activities, it was suggested that fish cages also contributed pollutant load to this lake. To maintain the sustainability of the lake, basic ecological information is necessary for the next study.
\end{abstract}

Keywords: Batang Antokan River, dissolved oxygen profile, Lake Maninjau, water quality

\section{INTRODUCTION}

Lake Maninjau is a large lake that including in the type of caldera lake (Santoso \& Batu UML, 2007). This lake is located in Agam District West Sumatra and has an important role for daily life and the beauty of the lake (Figure 1). Thereby, it has become the pride of the surrounding community. Currently, Lake Maninjau has economic functions as a power plant that produces the annual rate of $205 \mathrm{GWH}$ of energy, sources of irrigation water, catch fisheries, fish farming in floating cages, and tourism destination (Research Center for

\footnotetext{
* Corresponding Author. Tel: +62-218757071

E-mail: luki@limnologi.lipi.go.id
}

CMLI 2020
Limnology, 2001 \& Fakhrudin et al., 2002). Besides, from ecological functions, Lake Maninjau could control the water resources availability, microclimate, and habitat for organisms.

Regarding fish farming activities, this cultivation of fish in floating net began in 1990. Fish farming activities in floating net have increased the high economic growth for local communities. However, since 1997, this activity began to decrease because of frequent death of fish caused the loss of business. It caused a public complaint that a decrease in the lake's water quality is causing economic loss to the community or local government from both fish farming activities in the cages and tourism. 
Besides for fish farming in floating cages, Lake Maninjau is also used for tourist activities, especially by foreign tourists (Subehi et al., 2018). The development of tourism activities also led to the growth of the hotel or inn and restaurant around the lake. But the water quality of the lake such as murky water and odor caused a decline in tourist numbers and the impact on the economy of the community and local government

In early January 2009, more than 13 thousand tons of death of fish occurred at Lake Maninjau. The result of measuring the water quality of the lake from observation by Limnology station Research Centre for Limnology LIPI, in January 2009, reported a drop of dissolved oxygen (DO) $1.05 \mathrm{mg} / \mathrm{L}$ in water surface (normal conditions approximately $7 \mathrm{mg} / \mathrm{L}$ ) with temperatures $28^{\circ} \mathrm{C}$ and $\mathrm{pH}$ 7.17. At three meters of water depth, dissolved oxygen (DO) had reached $0.46 \mathrm{mg} / \mathrm{l}$, with a temperature of $27.2^{\circ} \mathrm{C}$. The water column is normally used for the floating cage. The low oxygen content was causing the mass death of fish. This disaster is related to what is called by local people as "tubo belerang" Generally, the tubo belerang phenomenon frequently occurs at the beginning of the year. Also, there is a possibility of circulation influence on the vertical profiles of dissolved oxygen in some of the lakes, where related to the seasonal meteorological patterns (Fukushima et al., 2017).
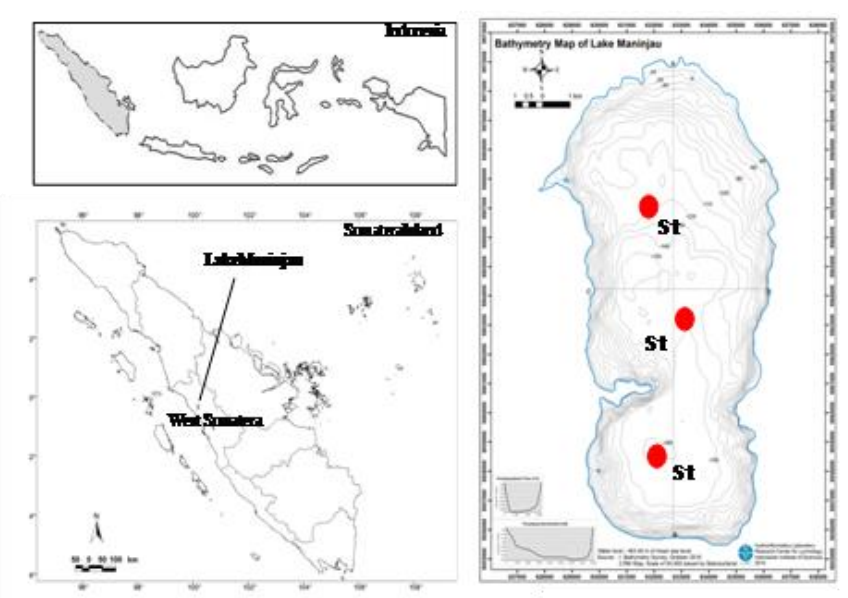

Figure 1. Locations of the study area

\section{METHODS}

Surveys at Lake Maninjau were conducted in August 2006, March 2014, September 2017, and April 2018. In order to get the data comprehensively, secondary data were also collected for supporting the analysis.

We conducted dissolved oxygen (DO) profile measurements in August 2006 by multi-probe sensor YSI 6600. Measurements were carried out until to the depth of $50 \mathrm{~m}$ with an interval of 0.4 m. Dissolved oxygen (DO) profiles were obtained with a range of 0 to $50 \mathrm{mg} / \mathrm{L}$, and resolution $0.01 \mathrm{mg} / \mathrm{L}$. Meanwhile, DO profile measurements in March 2014, September 2017, and April 2018 were taken from three locations at Lake Maninjau by RINKO-Profiler, supported by the University of Tsukuba, Japan. The logger version CTD profiler with optical fast DO sensor RINKO-Profiler was used for the survey. Depth (semiconductor pressure sensor with a range of 0 to $600 \mathrm{~m}$, and resolution $0.01 \mathrm{~m}$ ) and dissolved oxygen/DO (phosphorescence ranged 0 to 20 $\mathrm{mg} / \mathrm{L}$ and resolution $0.001 \mathrm{mg} / \mathrm{L}$ ) were obtained at each station. Measurements were carried out until to the depth of $160 \mathrm{~m}$ with an interval of 0.1 m.

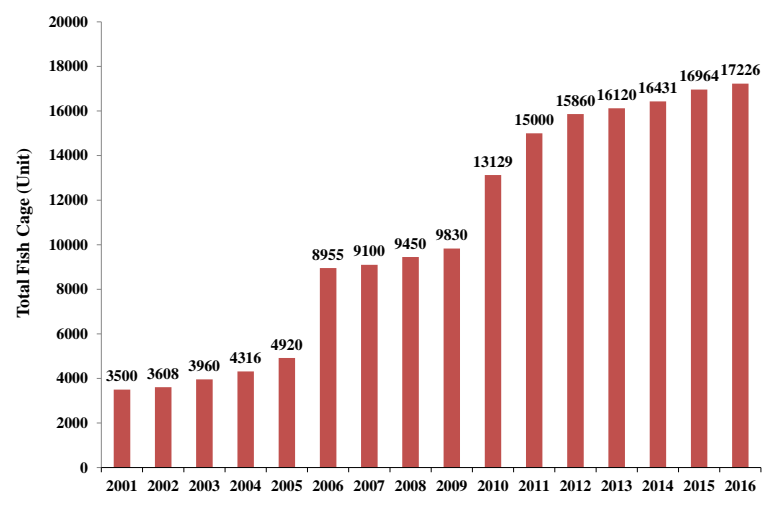

Figure 2. The number of fish cage at Lake Maninjau since 2001

Source: Agam Regency - West Sumatera (2016)

Finally, fish cages established at lake Maninjau was also observed and counted (Figure 2). At Lake Maninjau, there are approximately 16,000 units of fish cages in 2017, in general 
with a size $5 \times 5 \mathrm{~m}$ (Direktur Jenderal Perikanan Budidaya, Kementerian Kelautan dan Perikanan, 2014).

By campaigning "Save Maninjau" by local government (Agam Regency, 2018), they succeed in holding the growth rate of fish cages, and the total fish cage was 16,776 units and 17,226 units for 2017 and 2016, respectively.

\section{RESULTS AND DISCUSSION}

Lake Maninjau is located at an altitude of $461.5 \mathrm{~m}$ above sea level with a surface area of $9,737.5$ ha and a maximum depth of $165 \mathrm{~m}$. Lake Maninjau is a caldera lake formed by volcanic activity 60,000 years ago (Santoso, 2007). The source of water comes from rainwater and streams as well as the surrounding groundwater. This lake has an outlet called Batang Antokan flowing into the Indian Ocean, on West Sumatra's West Coast.

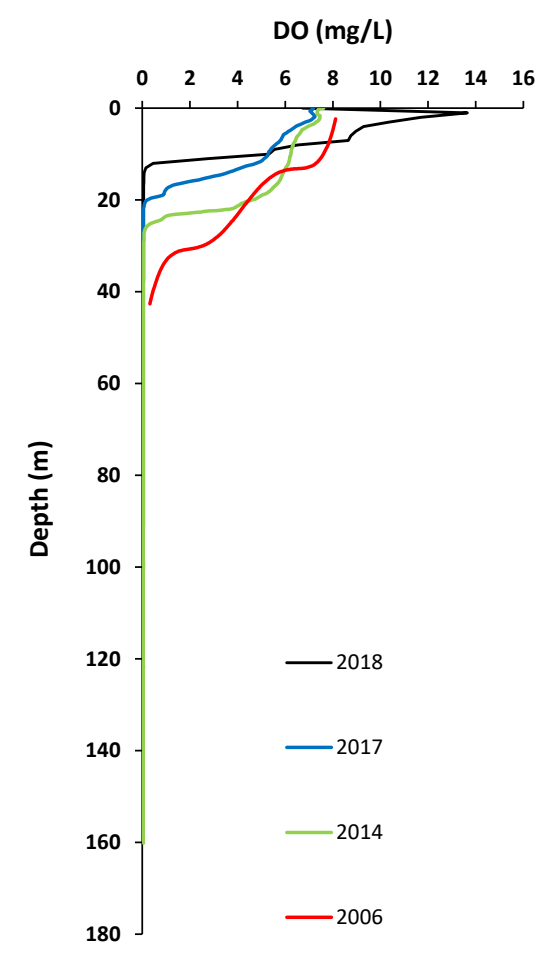

Figure 3. DO profiles at Lake Maninjau (August 2006, March 2014, September 2017, and April 2018)
Lake Maninjau, since 1983, has been used for power generation that the average annual production of $205 \mathrm{GWh}$, by building a dam at the outlet (Antokan River, which is the basis of the river at an altitude of $462 \mathrm{~m}$ ). The dam raised the water level of the lake from a height of $462 \mathrm{~m}$ from sea level to $464 \mathrm{~m}$. In addition, the outflow from the lake is used for power generation through the intake structure at the height of between $457.15 \mathrm{~m}$ to $453.75 \mathrm{~m}$ from sea level.

Based on Figure 3, high dissolved oxygen content in the surface layer and diminishing base from 2006 until 2018. Dissolved oxygen from the surface layer to a depth of $40 \mathrm{~m}$ (2006) has decreased to $12 \mathrm{~m}$ (2018), indicating the worse condition of water quality in 2018 compared with previous years.

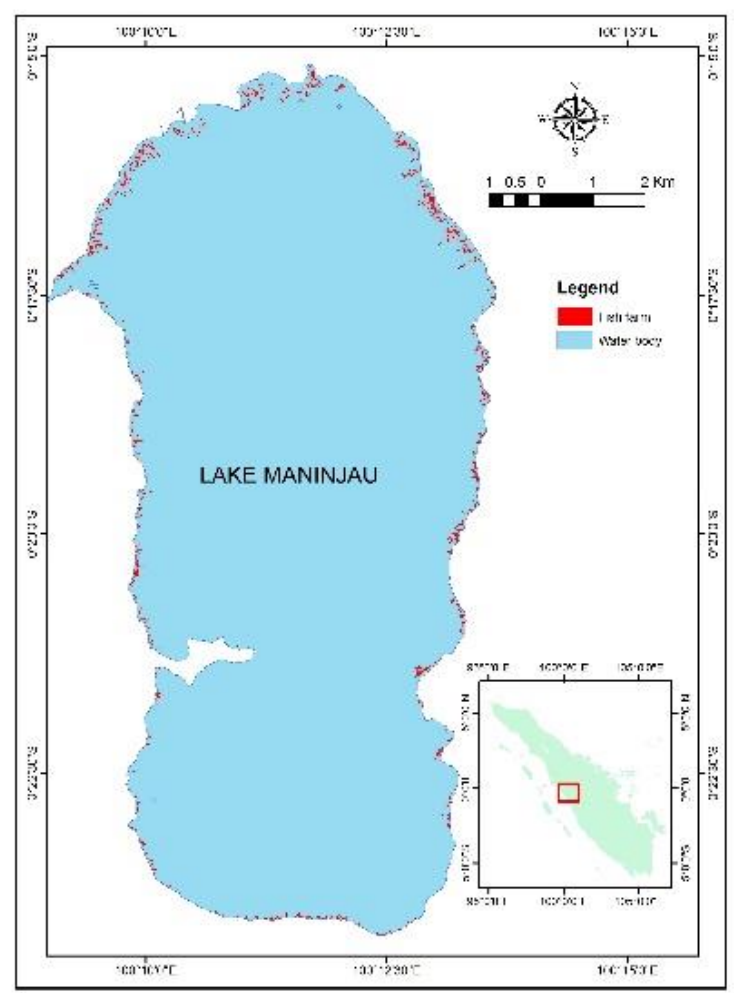

Figure 4. Distribution of fish cage (red color) in 2016 

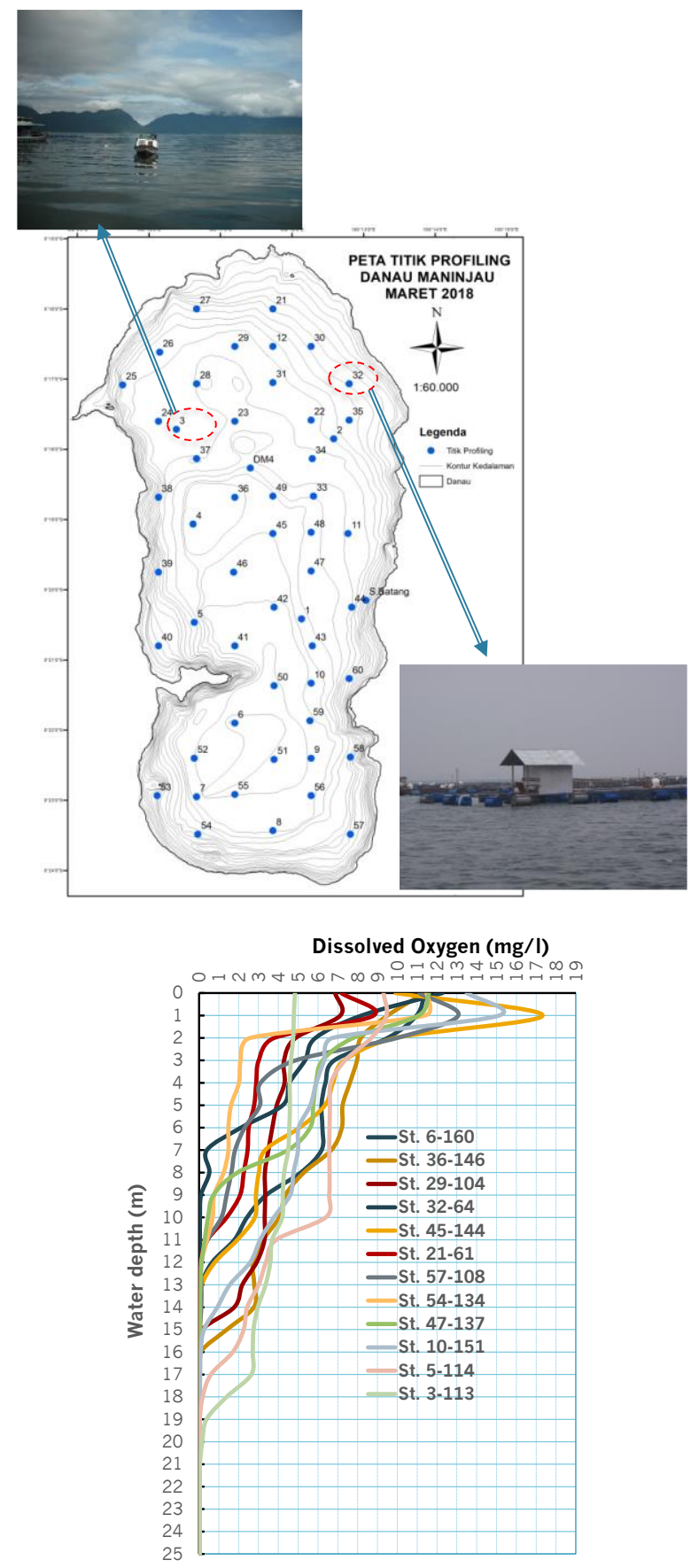

Figure 5. Location of St.3 and St. 32 related to DO profiles (March 12 -17, 2018); adapted from Fakhrudin et al. (2019)

Based on the survey and secondary data, we obtained the distribution of fish cages (Figure 4). Based on the distribution of fish cage locations, the DO profile was better at St. 3 near the outlet than St. 32 where many fish cages were observed (Figure 5). It could be explained that the location near the outlet, the pollutant flushed to the river compared with the location farther from the outlet and many fish cages

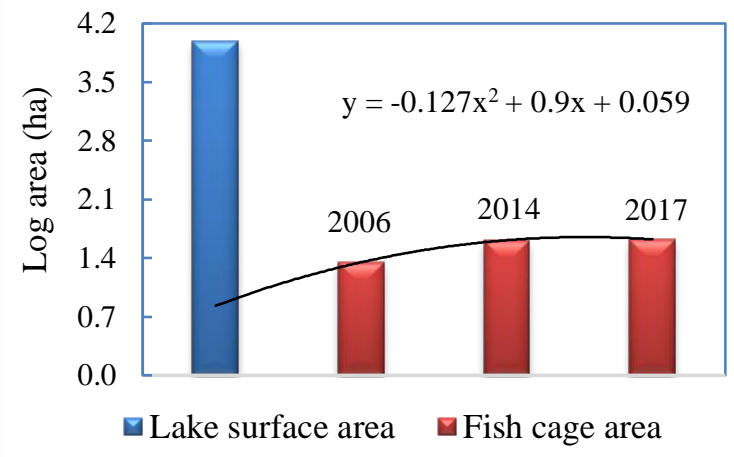

Figure 6. Comparison between the lake surface and fish cage areas for 2006, 2014 and 2017

Next, Figure 6 showed a comparison among fish cage areas (log area (ha)) in the three years observed. The fish cage areas were 22.4 ha, 41.1 ha, and 41.9 ha for 2006, 2014, and 2017, respectively. Moreover, the ratio between lake surface area and fish cage area (unit (ha) in logarithm) in percentage values were $0.23 \%$, $0.42 \%$, and $0.43 \%$ for 2006, 2014, and 2017, respectively. It indicated the growth of fish cages area as a pollutant also influenced water quality at Lake Maninjau.

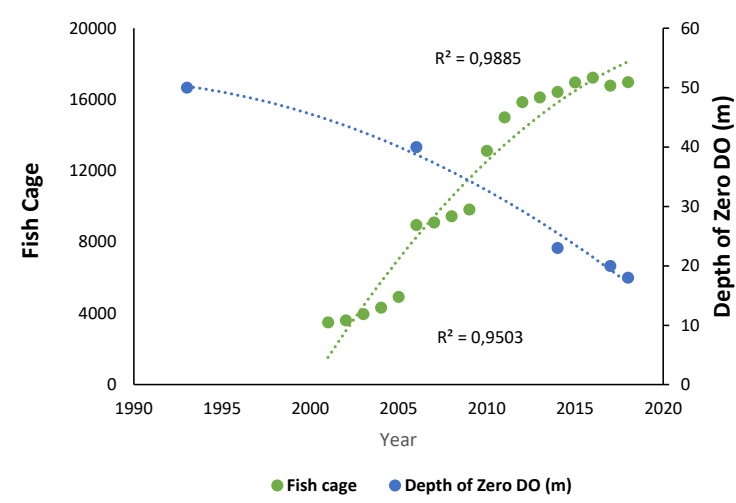

Figure 7. Depth of zero DO and fish cage conditions at Lake Maninjau

The increasing of fish cage influenced the decreasing of the depth of zero DO (Figure 7). It seems that the impact of fish cage activities, 
indicating more nutrient concentrations in the lake.

\section{CONCLUSION}

Lake Maninjau, as a caldera tropical lake and functioned in ecological and economic services, has faced various problems. Compared with previous years, the depletion of dissolved oxygen layer indicates the larger impact from human activities contributes to the water quality on the lake.

It found that the percentage value of the fish cage area at Lake Maninjau was higher in 2017 $(0.43 \%)$ than that in $2006(0.23 \%)$. Based on this ratio, the density of aquaculture indicated the potential impact i.e. pollutants from fish cages. Consequently, to maintain the sustainability of the lake, basic ecological information is necessary for the next study.

\section{ACKNOWLEDGEMENTS}

The authors would like to thank the Unit for Technology Transfer of Lake Restorations Indonesian Institute of Sciences (LATPD LIPI) and Agam Regency for supporting Lake Maninjau water quality data. In addition, the authors may thank to Research Center for Limnology LIPI.

\section{REFERENCES}

Agam Regency. 2018. Save Maninjau. Presentation of Agam Regency on JSPS Workshop, Tsukuba March.

Direktur Jenderal Perikanan Budidaya,Kementerian Kelautan dan Perikanan. 2014. Kebijakan pengelolaan perikanan buidaya di perairan umum daratan. Seminar Nasional Limnologi VII, LIPI, Cibinong, Bogor.

Fakhrudin M, Subehi L, Jasalesmana T, and Dianto A. 2019. Dissolved oxygen and temperature stratification analysis for early warning system development to prevent mass mortality fish in Lake Maninjau, West Sumatera - Indonesia. IOP Conf. Series: Earth and Environmental Science 2019 November, 380(1), 012002. DOI: $10.1088 / 1755-1315 / 380 / 1 / 012002$.

Fakhrudin M, Wibowo H, Subehi L, and Ridwansyah I. 2002. Karakterisasi Hidrologi Danau Maninjau Sumatera Barat. Prosiding Seminar Nasional Limnologi 2002. Pusat Penelitian Limnologi LIPI, $65-75$.

Fukushima T, Matsushita B, Subehi L, Setiawan F, and Wibowo H. 2017. Will hypolimnetic waters become anoxic in all deep tropical lakes? Nature; Scientific Reports, 7, 45320. DOI: 10.1038/srep45320Sci. Rep. 7, 45320, 1 - 8 .

Research Center for Limnology. 2001. Permasalahan Danau Maninjau dan Pendekatan Penyelesaiannya. Kerjasama Antara Proyek Pengembangan dan Peningkatan Kemampuan Teknologi dengan Puslit Limnologi LIPI, Cibinong-Bogor.

Santoso \& Batu UML. 2007. Morfogenesis daerah danau kaldera Maninjau, Sumatera Barat. Jurnal Sumber Daya Geologi, XVII(2), 91-104.

Subehi L, Siti Norasikin Ismail, Ridwansyah I, Muzzalifah Abd Hamid, and Mashhor Mansor. 2018. Analysis of the influence of reservoirs utilization to water quality profiles in Indonesia (Saguling - Jatiluhur) and Malaysia (Temengor Chenderoh) with special references to cascade reservoirs. IOP Conf. Series: Earth and Environmental Science, 118(1), 012025. DOI: 10.1088/1755-1315/118/1/012025. 